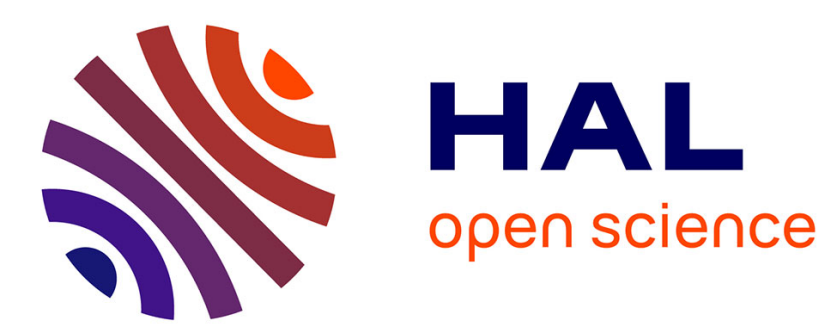

\title{
The effect of addition of lactic acid bacteria inoculum to wheat and corn silages in Israel
}

\author{
Zwi Weinberg, Gilad Ashbell, Norberto Lisker
}

\section{To cite this version:}

Zwi Weinberg, Gilad Ashbell, Norberto Lisker. The effect of addition of lactic acid bacteria inoculum to wheat and corn silages in Israel. Agronomie, 1987, 7 (9), pp.709-713. hal-00885045

\section{HAL Id: hal-00885045 \\ https://hal.science/hal-00885045}

Submitted on 1 Jan 1987

HAL is a multi-disciplinary open access archive for the deposit and dissemination of scientific research documents, whether they are published or not. The documents may come from teaching and research institutions in France or abroad, or from public or private research centers.
L'archive ouverte pluridisciplinaire HAL, est destinée au dépôt et à la diffusion de documents scientifiques de niveau recherche, publiés ou non, émanant des établissements d'enseignement et de recherche français ou étrangers, des laboratoires publics ou privés. 


\title{
The effect of addition of lactic acid bacteria inoculum to wheat and corn silages in Israel
}

\author{
Zwi WEINBERG, Gilad ASHBELL \& Norberto LISKER \\ Agricultural Research Organization, The Volcani Center, Bet Dagan, Israel
}

SUMMARY

\begin{abstract}
The effect of addition of a commercial Lactobacillus plantarum inoculum to wheat and corn silages (at $42.0 \pm 0.5,36.8 \pm 0.8 \%$ and $32.4 \pm 0.9,37.4 \pm 0.8 \%$ dry matter (DM), respectively) was studied. The experiments were carried out under laboratory conditions in 1.5 litre jars and with corn under farm conditions as well. The rates of change in $\mathrm{pH}$, water soluble carbohydrates (WSC), lactic acid production and DM balance were followed. The effect of aerobic exposure of the wheat silages on microbial counts and the numbers of epiphytic lactic-acid bacteria on wheat plants before ensiling were studied.

Results did not indicate any substantial advantage from the addition of the inoculum under the experimental conditions studied. However, it would be worthwhile to determine the conditions under which starter addition to silage would be beneficial.
\end{abstract}

Additional key words : $p H$, water soluble carbohydrates, dry matter, lactic acid.

Une étude a été effectuée sur l'inoculation d'une préparation commerciale de Lactobacillus plantarum à des ensilages de blé et de maïs dont les teneurs en matière sèche (MS) sont de 42,0,36,8 p. 100 et 32,4, 37,5 p. 100 respectivement. Les expériences ont été effectuées au laboratoire dans des bocaux de 1,5 litre, et également dans les conditions de la ferme pour le maïs. Les cinétiques du $\mathrm{pH}$, de disparition des sucres solubles, de la production d'acide lactique et le bilan DM ont été suivis. L'effet de l'exposition du blé à l'air sur les comptages microbiens et le nombre de bactéries lactiques épiphytes sur les plantes, avant ensilage, ont été étudiés. Dans les conditions de l'expérience, l'addition d'inoculum n'a pas montré d'avantages substantiels. Néanmoins, il serait souhaitable de déterminer les conditions dans lesquelles l'addition d'un inoculum est bénéfique.

Mots clés additionnels : $p H$, sucre soluble, matière sèche, acide lactique.

\section{INTRODUCTION}

Silage making is based on natural fermentation in which lactic acid is produced under anaerobic conditions, and as a result the $\mathrm{pH}$ decreases and the fodder is preserved.

During various stages of ensiling losses may occur (MCDONALD, 1981). A critical stage is during the first week of fermentation, when oxygen is still present and plant respiration and aerobic microorganisms are still active. These processes might lead to loss of nutrients and to spoilage and to production of undesirable end products. When oxygen is consumed, the $\mathrm{pH}$ decreases, the silage becomes stable and can be preserved for a long period. The rate and efficiency of acid production through fermentation by micro-

Contribution from the Agricultural Research Organization, The Volcani Center, Bet Dagan, Israel. No 1764-E, 1986 series. organisms are important factors in successful silage making and the most desirable microorganisms for ensuring this are the homafermentative lactic acid bacteria (WOOLFORD, 1984).

In Israel it is possible to grow wheat as a winter crop, in a double cropping system with a main summer crop such as cotton. However, due to the limited time available for the wheat it will not reach maturity, and the whole-crop wheat is best utilized for silage (ASHBELL et al., 1983). Silages of wheat harvested at the dough stage showed good aerobic stability, but silages of wheat harvested at the milk stage had considerable DM losses (ASHBELL et al., 1984). Corn in Israel is grown mainly for whole crop silage. Losses in corn silages may reach 20 p. 100 of DM (MCDONALD, 1981), but there is no specific information on losses of corn silages in Israel.

There is little information available on the epiphytic microflora of fodder crops (WOOLFORD, 1984). The 
type and number of the epiphytic microorganisms are dependent on various factors such as plant maturity, harvesting time, wilting and weather conditions (WOOLFORD, 1984). In order to ensure adequate numbers of lactic acid bacteria a commercially manufactured starter culture may be added to the ensiled crops. Information in the literature is not conclusive with regard to the advantages from adding such inoculants to silage crops. In some cases addition of bacteria was efficient (e.g. OHYAMA et al., 1975 ; CARPINTERO et al., 1979 ; LINDGREN et al., 1983), while in other works no advantage was found (e.g. THORNE, 1981 ; ELI et al., 1982 ; CARR et al., 1984).

So far the possibility of adding a bacterial inoculant to silages has not been tested under Israeli conditions (i.e. subtropical climate). The purpose of this investigation was to study the effect of a commercial inoculant on wheat and corn silages in Israel.

\section{MATERIALS AND METHODS}

\section{A. Experiments with wheat under laboratory condi- tions}

Chopped wheat (1 inch) of the varieties « Barkai » (Exp. 1) and "Inbar" (Exp. 2) harvested at the end of the milk stage, at $42.0 \pm 0.5$ p. 100 and $36.8 \pm 0.8$ p. 100 dry matter $(\mathrm{DM})$, respectively, were ensiled in 1.51 glass jars, equipped with a special lid with springs which enables gas release only (J. WECK, $\mathrm{GmbH}$ u. Co., Wher-Öflingen, W. Germany).

The jars were weighed on days $0,1,2,5,7,14$ and 60 of ensiling in each experiment. At each date, 2 jars chosen at random from each treatment were opened. The material from these jars was taken for dry matter determination and the rest was mixed together and samples were stored in closed plastic boxes at $-20^{\circ} \mathrm{C}$ for chemical analysis.

Commercial Lactobacillus plantarum inoculant was suspended in water, and $200 \mathrm{ml}$ of the bacterial suspension was sprayed on $15 \mathrm{~kg}$ of chopped wheat spread over an area of $1 \times 4 \mathrm{~m}$. This treatment enriched the wheat by $10^{5}$ viable lactic acid bacteria (LAB) per gram fresh material. This number was confirmed by enumerating the LAB colony forming units (CFU) in the commercial inoculant on Rogosa agar (Oxoid, CM627, Basingstoke, UK). To the control wheat only $200 \mathrm{ml}$ of water was added. The jars were stored at ambient temperature $\left(20 \pm 1{ }^{\circ} \mathrm{C}\right)$.

\section{B. Experiments with corn under laboratory conditions}

Corn of varieties 3358 (Exp. 1) and 180 (Exp. 2) harvested at the dent stage at $32.4 \pm 0.9$ p. 100 and $37.5 \pm 0.8$ p. $100 \mathrm{DM}$, respectively, were ensiled in glass jars as with the wheat. The inoculant was added at 2 concentrations, i.e. at $10^{6}$ and $10^{7} \mathrm{CFU}$ per gram fresh material (10 and 100 times that of the wheat). The jars were weighed and opened as in the experiment with the wheat.

\section{Experiments with corn under farm conditions in a bunker silo}

Weighed polyethylene net bags containing ca $3 \mathrm{~kg}$ chopped corn, (1 inch) var. "Hason" 451, at
37.6 p. $100 \mathrm{DM}$, where buried in a farm bunker silo on the day of ensiling. There were five control bags and five bags of corn treated with the inoculant at $10^{6} \mathrm{LAB} / \mathrm{g}$ fresh material. After 4.5 months, during the process of unloading, the bags were removed, weighed and samples were taken for $\mathrm{DM}, \mathrm{pH}$, watersoluble carbohydrates (WSC), and lactic acid determinations.

\section{Analysis}

\section{Dry matter}

DM was determined by oven drying at $60^{\circ} \mathrm{C}$ for $48 \mathrm{~h}$ for each jar separately. DM losses were assessed according to gas losses as measured by weight loss during the ensiling period.

\section{Preparation for $p H, W S C$ and lactic acid deter- minations}

Ten $\mathrm{g}$ of frozen silage (at $-20^{\circ} \mathrm{C}$ ) was blended for 2 min with $190 \mathrm{ml}$ of distilled water in a Waring Blender. The material was filtered through Whatman No. 1 paper and the filtrate was used for $\mathrm{pH}$, WSC, and lactic acid determinations.

\section{WSC determinations}

WSC determinations were performed by the colorimetric phenol-sulphuric-acid method, according to DUBOIs et al., 1956.

\section{Lactic acid determination}

Colorimetric determination of lactic acid was performed with kit no. 826 UV (Sigma, St. Louis, Mo. USA). With that method, lactic acid is oxidized to pyruvic acid by lactate dehydrogenase and NADH.

\section{The effect of exposure to air on the aerobic microbial counts of the wheat silage}

After 60 days of ensiling of each experiment, 2 jars from each treatment were opened and $20 \mathrm{~g}$ from each jar were placed separately in $250 \mathrm{ml}$ Erlenmeyer flasks closed with rubber stoppers. The stoppers were perforated with 2 needles, one connected to an air pump working at a rate of $600 \mathrm{ml}$ air $/ \mathrm{h}$, and the other needle free to release the surplus gases. The air was moistened by passing it through a water container, so that the relative humidity within the flasks was 100 p. 100. The flasks were stored for 7 days at $26 \pm 1{ }^{\circ} \mathrm{C}$. After 7 days the number of CFU of moulds, yeasts and aerobic bacteria was determined.

\section{Microbiological analysis}

The material from the Erlenmeyers was placed in $180 \mathrm{ml}$ sterile 0.1 p. 100 Bacto agar (Difco ; prepared with distilled water) and homogenized for $2 \mathrm{mn}$ in a Waring Blender. The homogenate was diluted ten-fold with 0.1 p. 100 agar. The bacterial CFU were determined on Difco nutrient agar containing $100 \mathrm{mg} / \mathrm{l}$ Actidione. Yeasts and moulds were determined in pour plates Jarvis agar (JARVIS, 1973) containing 
penicillin, streptomycin and tetracycline (Sigma) at 30, 30 and $10 \mathrm{mg} / \mathrm{l}$, respectively. All the petri dishes (in duplicates for each dilution) were incubated at $26 \pm 1{ }^{\circ} \mathrm{C}$ and the colonies were counted after a week.

\section{Epiphytic lactic acid-bacteria on wheat plants}

Fresh samples of chopped wheat for ensiling were brought to the laboratory from several near-by farms. The number of colonies of lactic acid bacteria was determined on Rogosa agar (Oxoid CM627, pour plate). Some of the samples were also ensiled in glass jars for 7 days, after which the number of colonies of lactic acid bacteria was determined again. The microbiological procedure for bacterial extraction was as described above. The petri dishes were incubated for 3 days at $30^{\circ} \pm 1{ }^{\circ} \mathrm{C}$.

\section{RESULTS}

\section{A. Wheat silage under laboratory conditions}

The effect of $L A B$ inoculum on the rate of $\mathrm{pH}$ change throughout the ensiling period in the wheat is shown in figure 1. In exp. 1, the $\mathrm{pH}$ of the inoculated wheat decreased more markedly and rapidly than the control and after 4 days of ensiling the difference was ca $0.4 \mathrm{pH}$ unit. In exp. 2, a similar trend was found but the difference was much smaller $(0.1 \mathrm{pH}$ unit). The final $\mathrm{pH}$, after 60 days of ensiling was similar (4.0) in both the control and the inoculated wheat. DM losses are presented in table 1. There was no clear-cut difference in DM losses $(<1$ p. 100 difference) between the control and the treated wheat.

Figure 2 describes the effect of inoculation on lactic acid production throughout the ensiling period in the wheat silages. In the inoculated wheat, there was 20 p. 100 more final lactic acid than in the control, in both trials.

The WSC content in the fresh wheat was high (11-17 p. 100 of DM) and decreased gradually to 7-12 after 60 days of ensiling, with no obvious differences between the control and the inoculated wheat.

The results of the aerobic exposure test do not indicate any significant advantage from the addition of the inoculum in preventing the development of detrimentral aerobic microorganisms. In the control, the mean $\log ( \pm$ S.D. between experiments $)$ of

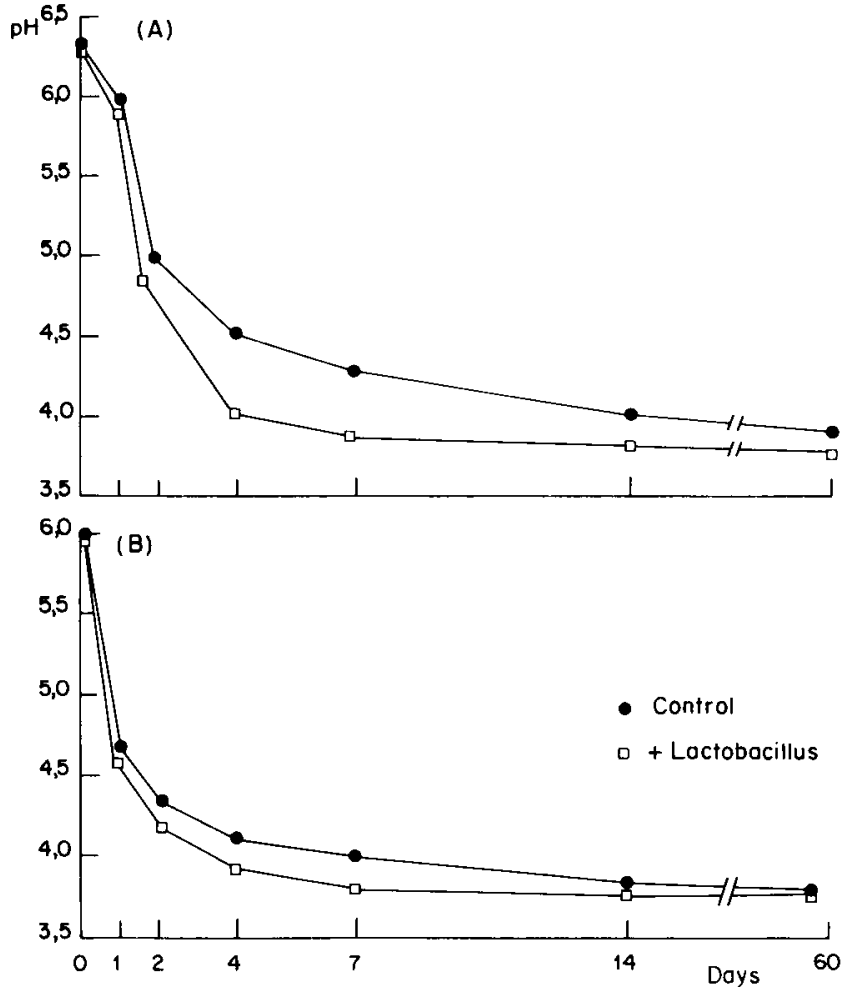

Figure 1

The effect of inoculum on the rate of $p H$ decrease in wheat silage throughout the ensiling period.

$A=$ Experiment $1 ; B=$ Experiment 2.

Effet de l'inoculum sur la cinétique de diminution du pH dans l'ensilage de blé (entre 0 et 60 jours).

$A=$ Expérience $1 ; B=$ Expérience 2.

number of CFU per gram DM of moulds, yeasts and aerobic bacteria increased from, respectively, $2.3 \pm 0.4$, $2.8 \pm 1.1$ and $4.0 \pm 1.4$ at the beginning of the experiment, to $3.0 \pm 0.3,7.5 \pm 5.2$ and $4.5 \pm 2.8$ after 7 days of air exposure. In the inoculated wheat, the mean log number of CFU per gram DM moulds, yeasts and aerobic bacteria, respectively changed from $3.2 \pm 0.1,4.5 \pm 0.6$ and $3.2 \pm 0.8$ at the beginning of the experiment, to $2.8 \pm 1.1,9.7 \pm 3.0$ and $5.4 \pm 3.6$ after 7 days of air exposure. From these results it can be seen that the numbers of yeasts increased dramatically in both the control and the inoculated wheat after 7 days of exposure to air.

The number of epiphytic lactic bacteria on the wheat from the various farms is given in table 2 . The numbers of these bacteria varied from $10^{2}$ to

TABLE 1

Percentage DM losses in the laboratory silages.

Pourcentages de pertes de MS dans les ensilages de blé et de maïs réalisés au laboratoire.

\begin{tabular}{|c|c|c|c|c|}
\hline \multirow{2}{*}{$\begin{array}{c}\text { Crop } \\
\text { Experiment }\end{array}$} & \multicolumn{2}{|c|}{ Wheat } & \multicolumn{2}{|c|}{ Corn } \\
\hline & 1 & 2 & 1 & 2 \\
\hline p. $100 \mathrm{DM}$ in fresh material & $42.1 \pm 0.5^{*}$ & $36.8 \pm 0.8$ & $32.4 \pm 0.9$ & $37.5 \pm 0.8$ \\
\hline p. $100 \mathrm{DM}$ loss in the control silages & $1.7 \pm 0.1$ & $3.0 \pm 1.0$ & $1.2 \pm 0.0$ & $1.2 \pm 0.1$ \\
\hline p. $100 \mathrm{DM}$ loss in the inoculated silage & $1.0 \pm 0.0$ & $3.5 \pm 0.4$ & $1.1 \pm 0.2^{* *}$ & $1.2 \pm 0.0^{* *}$ \\
\hline
\end{tabular}

* Mean \pm SD.

** Losses of the inoculated corn silages are those of the lower inoculation rate. However, for both inoculants concentration losses were very close. 

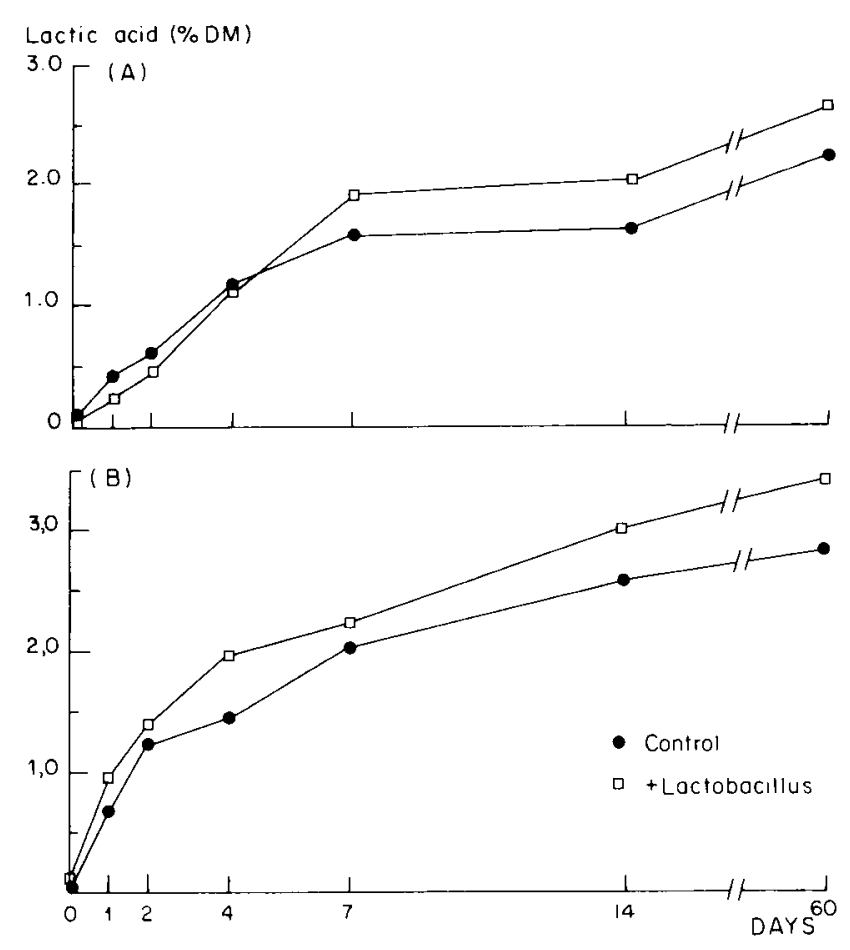

Figure 2

The effect of inoculum on lactic acid production in wheat silage throughout the ensiling period.

$A=$ Experiment $1 ; B=$ Experiment 2 .

Effet de l'inoculum sur la production d'acide lactique dans l'ensilage de blé entre 0 et 60 jours.

$A=$ Expérience $1 ; B=$ Expérience 2.

TABLE 2

Epiphytic lactic acid bacteria in wheat (CFU/g DM). Bactéries lactiques épiphytiques dans le blé (CFU/g MS) $(\mathrm{CFU}=$ Colony Forming Units).

\section{LAB (CFU/g DM)}

Farm

p. $100 \mathrm{DM}$

In fresh wheat

In wheat silage after 7 days

\begin{tabular}{llll}
\hline & & & \\
A & 38.2 & $6.9 \times 10^{4}$ & $1.1 \times 10^{9}$ \\
B & 37.0 & $1.7 \times 10^{4}$ & $9.8 \times 10^{8}$ \\
C & 31.8 & $3.4 \times 10^{6}$ & $1.2 \times 10^{9}$ \\
D & 40.9 & $3.8 \times 10^{4}$ & $4.8 \times 10^{8}$ \\
E & 48.0 & $4.2 \times 10^{4}$ & $7.0 \times 10^{8}$ \\
F & 56.0 & $8.0 \times 10^{2}$ & $5.0 \times 10^{8}$ \\
G & 58.9 & $2.4 \times 10^{7}$ & $6.4 \times 10^{8}$ \\
\hline
\end{tabular}

$10^{7} \mathrm{LAB} / \mathrm{g}$ of fresh material, and increased within one week to ca $10^{8} \mathrm{CFU} / \mathrm{g}$ DM in all samples tested. There was no apparent effect of the DM content in the fresh wheat on the numbers of the epiphytic LAB.

\section{B. Corn silage under laboratory conditions}

The effect of inoculum on the rate of $\mathrm{pH}$ change in the corn silages, throughout the ensiling period, is shown in figure 3 . No differences were observed between the control and the inoculated materials, even with the higher concentration of inoculum. No clearcut differences in DM losses were observed, similar to the results with wheat (table 1). Addition of the lactic
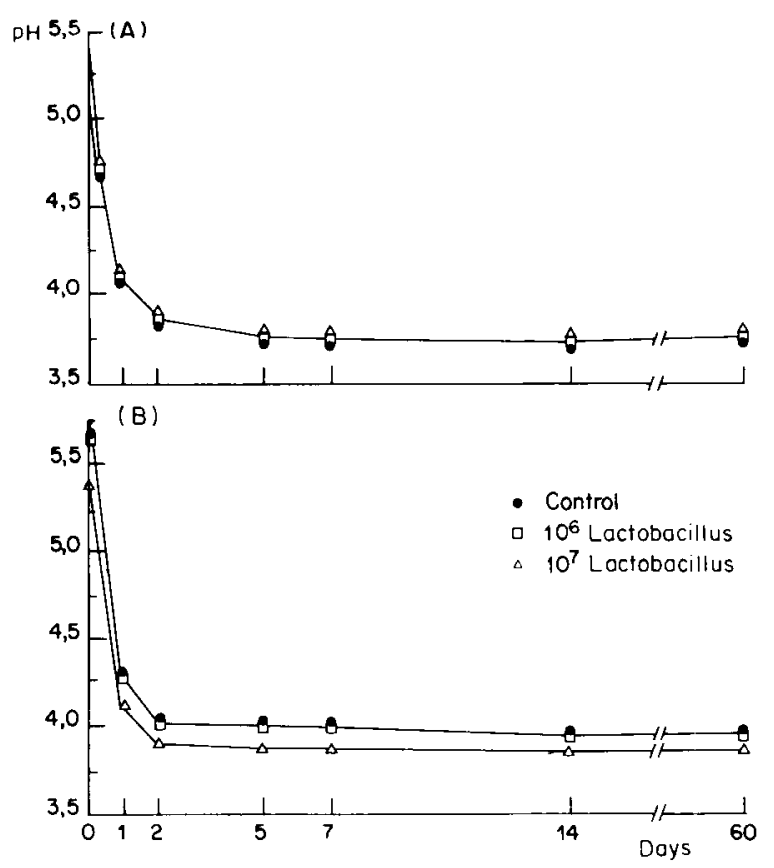

Figure 3

The effect of inoculum on the rate of $\mathrm{pH}$ decrease in corn silage throughout the ensiling period.

$A=$ Experiment $1 ; B=$ Experiment 2.

Effet de l'inoculum sur la cinétique de diminution $d u$ pH dans l'ensilage de mais entre 0 et 60 jours.

$A=$ Expérience $1 ; B=$ Expérience 2.

bacterial acid inoculum at both concentrations did not affect lactic production in the corn silages.

In the fresh corn, WSC content was ca 5 p. 100 in DM and decreased sharply after $2-5$ days to ca 1 p. 100 in DM. This was different from the gradual decrease in the WSC level in wheat. The inoculum did not affect the WSC content in corn.

\section{Corn silage in bunker silo}

The results of this experiment indicated somewhat lower DM losses in the inoculated corn silage than in the control (mean of $4.1 \pm 1.0$ vs $6.1 \pm 1.0$ p. 100 , respectively). However, the differences were not significant at $P=0.05$. No differences were found between the treated and the control silages in $\mathrm{pH}$ or lactic acid content.

\section{DISCUSSION}

The success of an inoculant as a silage additive depends on many factors, such as type and properties of the plants to be ensiled, weather conditions, epiphytic microflora, the way the silage was prepared, and of course the properties of the inoculant per se (HENDERSON \& MCDONALD, 1984).

The results obtained in this study do not reveal any substantial advantage from the addition of $L$. plantarum inoculum to wheat and corn silages, under our specific experimental conditions. In the laboratory trials, conditions were optimal with regard to compaction and sealing of the silage. No effect of the initial DM content on losses was apparent in the tested ranges. In the bunker silo, under farm 
conditions the effect of inoculum addition could be more obvious. Indeed, smaller DM losses were observed in the inoculated material but so far without significant differences. The methodology of burying net bags in bunker silos to study various effects proved to be very efficient. Since the DM content of the cereal crops under the Israeli conditions is rather high there are no seepage problems that could distort the results, as there probably are in moist material.

Little information is available on the effect of inoculants on wheat and corn silages. ELI et al. (1982) added a mixture of $L$. acidophilus and Candida spp. to alfalfa, corn, sorghum and wheat silages in large silos and CARR et al. (1984) added a commercial (unspecified) inoculant to corn silage in farm experiments. In these studies, no advantage was found with regard to losses of digestible DM. These findings agree with our results with the $L$. plantarum inoculum added to corn and wheat silages. THORNE (1981) added L. acidophilus and HENDERSON \& MCDONALD (1984) added various LAB inoculants to grass silages, also with little effect. On the other hand, OHYAMA et al. (1975) who added $L$. plantarum along with glucose to Italian ryegrass and cocksfoot obtained high quality silages and a rapid suppression of aerobic gram negative bacteria. PAHLOW (1982) achieved better aerobic stability with a commercial lactobacillus inoculant in grass silages under laboratory conditions. LINDGREN et al. (1983) obtained a 30 p. 100 reduction in total DM losses in grass silages when using a mixture of Pediococcus acidolactici and L. plantarum. CARPINTERO et al. (1979) added a mixed strain inoculum (consisting of $L$. plantarum, L. mesenteroides and $S$. faecalis) with a glucose supplement to ryegrass-clover silage under laboratory conditions. They claimed a reduction in proteolysis and higher lactate levels in the inoculated silage, but did not indicate DM losses.

Our results did not indicate improved aerobic stability of the inoculated silages. Some reports in the literature indicate improved aerobic stability of various silages due to inoculation, while other studies indicated enhanced aerobic deterioration of inoculated silages (SEALE, 1986). Yeasts are probably a major deteriorative factor (BECK \& GROSS, 1964, as cited by SEALE, 1986). Yeasts were found in very large numbers in our wheat samples that were exposed to air. If the inoculant could inhibit the yeasts by producing various volatile organic acids (such as acetic acid) then it could improve aerobic stability of the silage (MCDONALD, 1981).

Since the addition of the inoculant to the wheat and corn silages did not result any obvious advantage, we decided to determine the number of epiphytic lactic acid bacteria on wheat samples from various farms. This could explain the inoculation results. The epiphytic LAB population found in these wheat samples was rather large. The numbers of LAB did not correlate with DM content of the wheat, nor with the daily weather conditions. Wheat for silage in Israel is harvested in the spring, when temperature changes are rapid and extreme (the range is between $15-45^{\circ} \mathrm{C}$, with very dry warm winds or slight rainfall). In all the samples that were studied, the LAB developed spontaneously to very high numbers within a week of ensiling. It could well be that the addition of $10^{5}-10^{7} \mathrm{CFU} / \mathrm{g}$ fresh material to a crop already containing large numbers of LAB was not effective. The numbers of LAB found in the local wheat were comparable to those found in other fresh crops for silage, such as grass (WOOLFORD, 1984, LINDGREN et al., 1983).

The effect of addition of different inoculants under various conditions, on silage quality in Israel, is being investigated in our laboratory.

Reçu le 8 décembre 1986 Accepté le 7 juillet 1987

\section{REFERENCES}

Ashbell G., Theune H. H., Sklan D., 1983. Changes in the amino acid compounds of the whole crop wheat during ensiling and after fermentation. J. Sci. Food Agric., 34, 321-327.

Ashbell G., Theune H. H., Sklan D., 1984. Composition and aerobic stability of silage made from whole wheat or from ears or stems of wheat at two growth stages. $J$. Sci. Food Agric., 35, 389394.

Carpintero C. M., Henderson A. R., McDonald P., 1979. The effect of some pre-treatments on proteolysis during the ensilage of herbage. Grass Forage Sci., 34, 311-315.

Carr S. B., Hammes R. C., Moes A. J., McGilliard M. L., 1984. Corn silages preservation with anhydrous ammonia, live culture microbial or organic acid-based additives. J. Dairy Sci., 67, 1474-1481.

Dubois M., Giles K. A., Hamilton J. K., Rebes P. A., Smith F., 1956. Colorimetric method for determination of sugar and related substances. Anal. Chem., 28, 350-356.

Eli L. O., Moon N. J., Sudweeks E. M., 1982. Chemical evaluation of Lactobacillus addition to alfalfa, corn, sorghum and wheat forage for ensiling. J. Dairy Sci., 65, 1041-1046.

Henderson A. R., McDonald P., 1984. The effect of a range of commercial inoculants on the biochemical changes during the ensilage of grass in laboratory studies. Res. Devel. Agric., 1 (3), $167-171$.
Jarvis B., 1973. Comparison of an improved rose bengal chlorotetracycline agar with other media for the selective isolation and enumeration of moulds and yeasts in food. J. Appl. Bacteriol., 36, 723-727.

Lindgren S., Lingvall R., Kaspersson A., Kartzow A., Rydberg E., 1983. Effect of inoculants, grain and formic acid on silage fermentation. Swedish J. Agric. Res., 13, 91-100.

McDonald P., 1981. Losses during ensilage, In : The Biochemistry of silage, John Wiley \& Sons, Chichester England, pp. 168-178.

Ohyama Y., Morichi T., Masaki S., 1975. The effect of inoculation with Lactobacillus plantarum and addition of glucose at ensiling on the quality of aerated silages. J. Sci. Food Agric., 26, 1001-1008.

Pahlow G., 1982. Improvement of the aerobic stability of silage by inoculant. Das Wirtschaftseigene Futter, 28, 107-122.

Seale D. R., 1986. Bacterial inoculants as silage additives. J. Appl. Bacteriol. Symposium Suppl., 9S-26S.

Thorne D. M., 1981. The microbiology of $\mathrm{H} / \mathrm{M}$ inoculant silage additive. Proc. 6th Silage Conf. (Edinburgh), paper No. 35.

Woolford, M. K., 1984. The microbiology of silage, In : The silage fermentation, Marcel Dekker Inc., New York, N.Y., U.S.A., pp. 35-42. 